\title{
DEVELOPMENT OF LABORATORY WORK MODULE FOR PRODUCTION OF SOAP BASED ON LOCAL RESOURCES AS THE INTEGRATION OF CHEMISTRY LESSONS WITH WORKSHOP AND ENTREPRENEURSHIP
}

\author{
Andi Maria Ulfa ${ }^{1 *}$, Amirul Hilmi ${ }^{2}$ and Isna Rezkia Lukman ${ }^{3}$ \\ ${ }^{1}$ Fisheries Resource Utilization Study Program, Faculty of Agriculture, University of Cordova, NTB, Indonesia \\ ${ }^{2}$ Industrial Engineering Study Program, Faculty of Engineering, University of Cordova, NTB, Indonesia \\ ${ }^{3}$ Chemistry Education Study Program, Faculty of Teacher Training and Education, Malikussaleh University, \\ NTB, Indonesia \\ *Email: yayaqe06011991@gmail.com
}

Accepted: January 03, 2022. Approved: January 09, 2022. Published: January 16, 2022

\begin{abstract}
The study aims to develop and test the feasibility of a locally developed soap-making module based on local resources. The research method used is research and development (R\&D), which is adapted from the Borg \& Gall R\&D method. There are ten stages of research with three stages of testing/assessment. Stage I assessment by experts (chemistry/chemistry learning, economics/economics learning, language, and graphic design), stage II assessment by peer reviewers/colleagues, and stage III assessment by chemistry teachers and teachers of crafts and entrepreneurship. The assessment results by experts got a total score of 58, which was in the good category. The assessment results by economists/learning economics got a total score of 72 , which was in the very good category. The result of the assessment by the linguist got a total score of 57 in the very good category. Finally, the result of the assessment by the graphic design expert got a score of 39 in the good category. The second stage of the assessment by five peer reviewers received an average total score of 69.6 in the good category, while the assessment results by the chemistry teacher and PKwu were 72.6 and 74 in the very good category, respectively. The overall assessment results show that the module is in the good and very good categories; therefore, the module is feasible to be developed and used further. While the results of the assessment by the chemistry teacher and PKwu, respectively, were 72.6 and 74, with a very good category. The overall assessment results show that the module is in the good and very good categories, so it can be concluded that the module is feasible to be developed and used further.
\end{abstract}

Keywords: Module, Soap-Based on Local Resources, Integration Lessons

\section{INTRODUCTION}

The local government of the West Sumbawa Regency (KSB) has policies that encourage increased economic growth. One of them is improving the investment climate, especially in the field of natural resources (SDA) [1]. Natural resources have an essential role in human life, even for various communities in Indonesia. Natural resources have economic value and social, cultural, and political [2]. Natural resource management and development can improve the economy. In KSB, natural resource processing products have begun to be developed through MSMEs and BumDes' empowerment and have started to fill modern retail stores. Currently, the economic value of a product or service emphasizes creativity and the creation of innovation through increasingly advanced technological developments. The new economic era prioritizes information and creativity, popularly known as the Creative Industry or Creative Economy [3].

In addition to developing creative industries in the community, the government has also begun to develop students' abilities in finding, redesigning, and developing products that are implemented in craft and entrepreneurship subjects through primary and secondary education. There are four aspects to these subjects, namely crafts, engineering, cultivation, and processing, which are directed at developing products using appropriate technology on a home industry scale with entrepreneurial insight to be economically independent [4]. In addition, in the 2013 curriculum, students are required to have knowledge competence (KI3) and skills (KI4) to increase knowledge and apply it to solve problems in everyday life.

Teachers are required to integrate various fields of knowledge into a single unit to create an actual learning process and directly impact life. In chemistry, students learn about chemical reactions, bases, proteins, and fats which are the main ingredients for making soap. Unfortunately, the learning that has been carried out so far is still only focused on delivering material from the teacher to the students. Most of the concepts in Chemistry are abstract, microscopic, tiered, and structured. It causes students to be required to understand the whole concept because each concept at a certain level will affect concepts at other levels [5],[6]. Then in the subjects of crafts and entrepreneurship, one of the aspects studied is processing directed at product development.

Schools in KSB have not implemented the integration of the two subjects. The initial study results show that some schools still do not 
have a laboratory. In crafts and entrepreneurship, students are only directed to make a craft. In contrast, for processing, students are usually directed to complete KSB specialties which are served only during the assessment. Processing natural resources into a product with economic value certainly makes learning more meaningful.

The 2013 curriculum framework places craft and entrepreneurship education as mandatory subjects. It emphasizes aspects of the use of science and technology and local cultural wisdom. The implementation of these two aspects can be carried out in activities to produce crafts, engineering, cultivation, and processing [7]. Entrepreneurship education is combined with crafts combined to develop creative abilities because entrepreneurship will not run without creating products of sale value [8]. For this reason, the integration between craft and entrepreneurship subjects with chemistry subjects is considered very suitable to help teachers and students develop their potential and natural resources in KSB. One of them is through the practice of making soap based on local resources at KSB.

The soap made in this module is transparent. In the formulation, the main ingredients are coconut oil and palm oil, which are reacted with $\mathrm{NaOH}$ base with the addition of glycerin, sucrose, alcohol, and other transparent agents. Besides being attractive in appearance, transparent soap can treat skin well because it contains glycerin and sugar, which also functions as a humectant [9]. In principle, any oil can be used as raw material for making transparent soap. VCO virgin coconut oil[10], palm oil[11], even used cooking oil[12] have been used as raw materials for making transparent soap. Transparent soap can also be made from coconut oil and castor oil[13] or a mixture of coconut oil, palm oil, and olive oil[14].

The choice of making transparent soap is also due to the simple process, namely the reaction between fat and alkali, which produces soap and glycerol, which can be seen in Figure 1 [16].

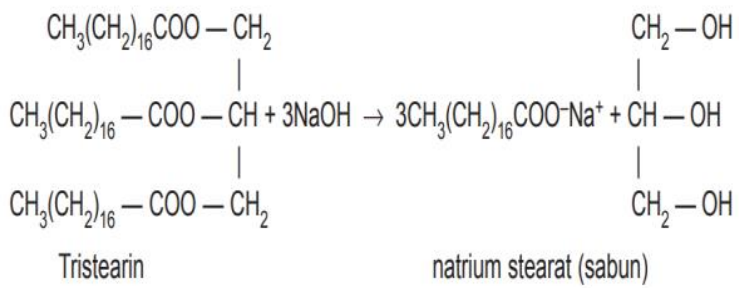

Picture 1. Saponification reaction (saponification) of fat with an alkali

Learning modules are teaching materials arranged systematically and attractively, including material content, methods, and evaluations that can be used independently to achieve the expected competencies and learning objectives [16][17]. Teaching materials in the form of modules are designed to assist teachers in providing learning experiences that involve mental and physical processes through interactions between students, students and teachers, the environment, and other learning resources to achieve the expected competencies [18]. In addition, through the modules developed, it is expected to encourage students to make connections between the knowledge they have and their application in everyday life.

Through the development of this module, it is hoped that it can become a learning resource that can be used by teachers and students in the learning process with an integrated system of chemistry subjects with crafts and entrepreneurship. So the research aims to develop and test the feasibility of the locally developed soap-making module based on local resources.

\section{RESEARCH METHODS}

The research method used is the research and development (R\&D) method which refers to the Borg \& Gall development model [10]. The research stages used are the modifications of the Borg \& Gall development model with ten stages, as shown in Figure 2.

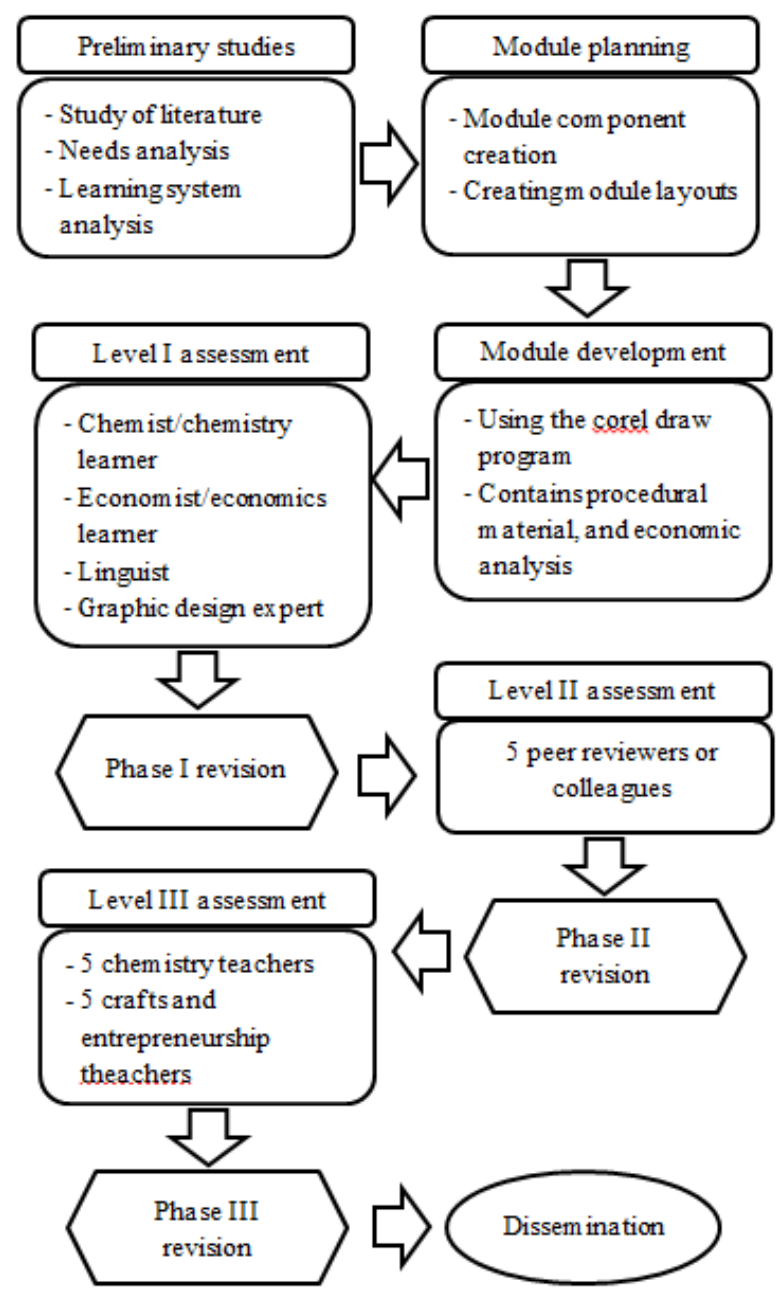

Figure 2. Research stages 


\section{Preliminary studies}

1) Study of literature

We are collecting information from journals and materials in the curriculum for chemistry and crafts and SMA/MA entrepreneurship lessons.

\section{2) Needs Analysis}

Formulate the content or material about soap, the procedure for its manufacture, and its economic analysis.

\section{3) Learning System Analysis}

We are analyzing the Core Competencies (KI) and Basic Competencies (KD) of Chemistry learning and crafts and SMA/MA entrepreneurship based on the 2013 Curriculum.

\section{Planning module}

\section{1) Module components Pembuatan}

Materials, pictures, and display designs and designs are designed at this stage. Material manuscript validated by experts in chemistry, economics, and language. At the same time, graphic design experts validate the images and display designs.

2) Making Module Layout

The layout is a visualization of ideas to be built to provide an overview of the modules that will be produced.

\section{Development Module}

Development module using the Corel Draw program.

\section{Evaluation Stage I}

Modules are assessed by a chemist, an economist, a linguist, and a graphic design expert. The assessment covers aspects of material, language, and module appearance.

\section{Revision Phase I}

Revise according to the results and inputs obtained in the first stage of the assessment.

\section{Stage II Assessment}

Five colleagues (lecturers of the University of Cordova) assessed the results of the first phase of the revision by assessing the module's material, linguistic, and display aspects.

\section{Phase II Revision}

Revise according to the results and inputs obtained in the second stage of the assessment.

\section{Stage III assessment}

The revision results in the second stage of the assessment were then assessed by ten high school teachers (5 chemistry teachers and five crafts and entrepreneurship teachers) by assessing the material, linguistic, and module display aspects.

\section{Phase III Revision}

Revise according to the results and input obtained from the stage III assessment

\section{Dissemination}

At this stage, research results are reported in scientific meetings, journal publications, and ISBN processing.

\section{RESULTS AND DISCUSSION}

Based on Phase I assessments by chemists/learning chemists, economists/economic learning experts, linguists, and graphic design experts, the results indicate that the developed modules are feasible to be assessed or processed to the next stage. With some notes/revisions. The results can be seen in Figure 2.

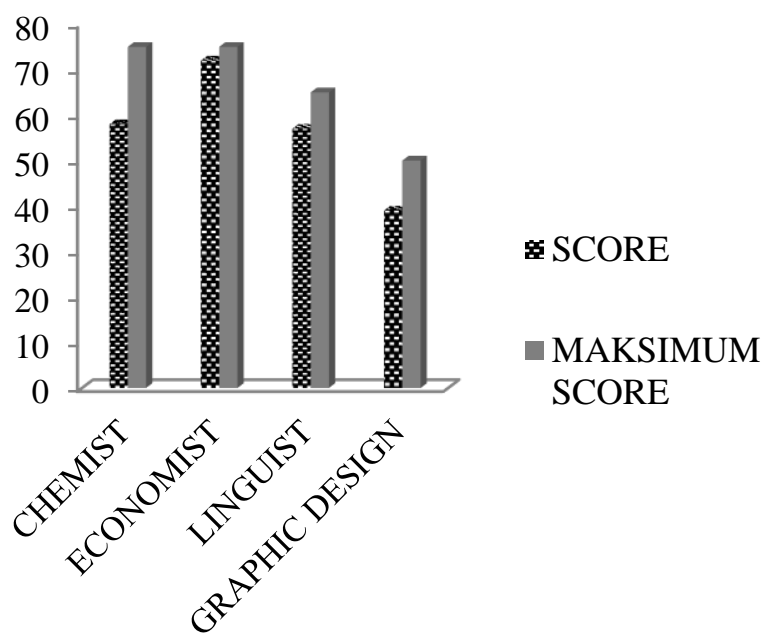

Figure 3. Expert Assessment Results

In the assessment of chemists/chemistry studies and economists/economics studies, 4 aspects are assessed, namely 1) the suitability of the material with KI and KD (3 statements); 2) the accuracy of the material (6 statements); 3) supporting learning materials (3 indicators), and 4) material updates (3 statements). The total statements are 15 statements. The chemist's assessment/chemistry learning results show that the total score of the fifteen statements is $\mathbf{5 8 \text { from }}$ the maximum total score of 75 . Based on table 1 , the chemist's assessment/chemistry learning results are in the GOOD category with a score range of $50.95-62.82$. For the assessment results of economists/economic studies, the total score of the fifteen statements is 75 out of the maximum total score of 75 . Based on table 1 ,

In the assessment of linguists, six aspects are assessed, namely 1) straightforward (3 statements); 2) communicative (2 statements); 3) dialogical and interactive (2 statements); 4) conformity with the level of development of students (2 statements); 5) coherence and 
coherence in the flow of thought (2 statements); and 6 ) the use of terms, symbols, or icons (2 statements), so a total of 13 statements. The results of the linguist's assessment showed a total score of 57 from the maximum total score of 65 .

Based on table 1, the results of the linguist's assessment were in the VERY GOOD category.

In the graphic design expert's assessment, three aspects are assessed, namely 1) module size (2 statements), module cover design (3 statements), and 3 ) module content design (5 statements), so that there are a total of 10 statements. The graphic design expert's assessment results showed a total score of 39 out of a maximum total score of 50. Based on table 1, the graphic design expert's assessment results were in a GOOD category.

Table 1. Category of module assessment results

\begin{tabular}{ccc}
\hline No & Score range & Category \\
Chemist/Economist & \\
\hline 1 & $x>62,82$ & Very good \\
2 & $62,82>x>50,94$ & Well \\
3 & $50,94>x>39,06$ & Enough \\
4 & $39,06>x>27,18$ & Not enough \\
5 & $27,18>x$ & Very less \\
\hline Linguist $\quad$ & \\
1 & $x>54,44$ & Very good \\
2 & $54,44>x>44,15$ & Well \\
3 & $44,15>x>33,85$ & Enough \\
4 & $33,85>x>23,56$ & Not enough \\
5 & $23,56>x$ & Very less \\
\hline Graphic Design Expert & \\
1 & $x>41,88$ & Very good \\
2 & $41,88>x>33,96$ & Well \\
3 & $33,96>x>26,04$ & Enough \\
4 & $26,04>x>18,12$ & Not enough \\
5 & $18,12>x$ & Very less \\
\hline Peer Reviewer and teacher (Chemistry \& \\
Workshop and entrepreneurship Lesson) \\
1 & $x>67$ & Very good \\
2 & $67>x>54,34$ & Well \\
3 & $54,34>x>41,66$ & Enough \\
4 & $41,66>x>28,99$ & Not enough \\
5 & $28,99>x$ & Very less \\
\hline \multicolumn{4}{c}{ Dor } \\
\hline
\end{tabular}

From the results of the first stage of the assessment, several revisions were made to the module, namely 1) the replacement of several animated images into real images; 2) addition of information "did you know?" on some parts of the module; 3) changes to the evaluation; 4) correction of the wrong words in the typing, and 5) match the color of the entire table.

Next, the second stage of the assessment was carried out by peer reviewers, and the third stage by the chemistry teacher and craft and entrepreneurship teacher with the results, which can be seen in Figure 4.

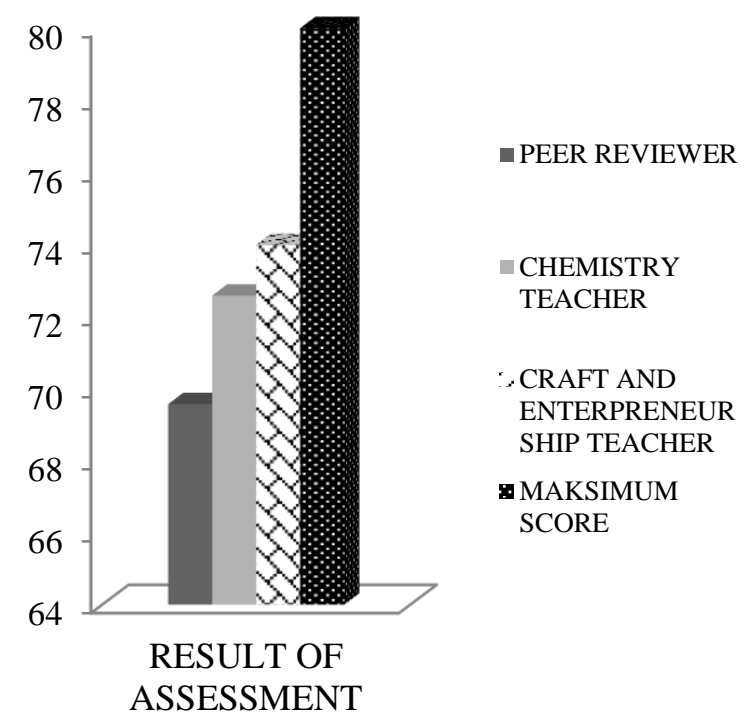

Figure 4. Results of Phase II and III Assessments

Based on the results of the second stage of assessment by peer reviewers and the third stage of assessment by chemistry teachers and $\mathrm{PKwu}$, the instruments used were the same, namely that three aspects were assessed. Aspect 1) learning (4 statements); 2) material (6 statements); and display (6 statements), so there are a total of 16 statements. Assessment by peer reviewers/peers gets a total score of 69.9 out of a maximum score of 80 . Based on table 1 , the assessment results by peer reviewers/peers are in a GOOD category. As for the chemistry teachers and PKwu teachers, the total scores were 72.6 and 74 , respectively, which, based on table 1 , were in the VERY GOOD category.

The revisions carried out in phase II were, 1) adjusting the objectives to the indicators; 2) adding supporting images; 3 ) adding chemicals regarding laboratory safety; 4) improving the color of the cover design.

After revising stage II and stage III assessments, the revision was carried out again based on the stage III assessment by the chemistry teacher and PKwu. The revisions made were 1) adding a SWOT analysis; and 2) improving the cover design.

After the revision of stage III is complete, the average results of the assessment stage I to stage III are in the very good and good category. It can be said that the developed module is feasible to be disseminated or informed to the public, who can take advantage of the module/module development research results. At this stage, the researcher publishes in writing in the journal also officially publishes the module. 


\section{CONCLUSION}

The module developed is a soap-making laboratory work module based on KSB's local resources, which is tested for feasibility through a gradual assessment. The assessment results show that the module is in the very good and good categories, so it is feasible to be developed/used further in the learning process.

\section{REFERENCES}

[1] BPMPPT KSB. (2016). Kajian Potensi SDA Dalam Rangka Promosi Investasi. Taliwang : BPMPPT KSB.

[2] Hidayat (2011). Pengelolaan Sumberdaya Alam Berbasis Kelembagaan Lokal. Jurnal Sejarah CITRA LEKHA, 15(1), 19-32

[3] Fitriana, A. N., Noor, I., dan Hayat, A. (2014). Pengembangan Industri Kreatif di Kota Batu (Studi Tentang Industri Kreatif Sektor Kerajinan di Kota Batu). Jurnal Administrasi Publik (JAP), 2(2), 281-286.

[4] Kemendikbud. 2017. Model Silabus Mata Pelajaran Sekolah Menengah Atas/Madrasah Aliyah/Sekolah Menengah Kejuruan/Madrasah Aliyah Kejuruan (SMA/MA/SMK/MAK) Mata Pelajaran Prakarya Dan Kewirausahaan. Jakarta : Kemdikbud.

[5] Mentari, L. (2018). Analisis Miskonsepsi Siswa SMA pada pembelajaran Kimia untuk materi larutan penyangga. E-journal Kimia Visvitalis Universitas Pendidikan Ganesha, 2(1), 76-87

[6] Prabowowati, K. (2014). Penerapan Media Chemschool Dengan metode guided note taking pada pemahaman konsep siswa. Jurnal inovasi pendidikan Kimia, 8(2), 1319-1329

[7] Depdiknas. 2014. Peraturan Pemerintah No. 19 tentang Standar Nasional Pendidikan.

[8] Napitulu, E. L. (2013). Guru kewirausahaan disiapkan. Kompas.com, p.1.

[9] Devi, P. K., Karyana, S., Nulhakim, L. 2018. Senyawa Organik: Pembuatan Sabun. Bandung: SEAMEO QITEP In Science.

[10] Sari, T. I., Herdiana, E., \& Amelia, T. (2010). Pembuatan VCO dengan Metode Enzimatis dan Konversinya Menjadi Sabun Padat Transparan. Jurnal Teknik Kimia, 17(3), 5058.

[11] Widyasanti, A., Farddani, C. L., \& Rohdiana, D. (2016). Pembuatan Sabun Padat Transparan Menggunakan Minyak Kelapa Sawit (Palm Oil) dengan Penambahan Bahan Aktif Ekstrak Teh Putih (Camellia Sinensis). Jurnal Teknik Pertanian Lampung (Journal of Agricultural Engineering), 5(3), 125-136.

[12] Priani, S. E., \& Lukmayani, Y. (2010). Pembuatan Sabun Transparan Berbahan Dasar Minyak Jelantah Serta Hasil Uji Iritasinya pada Kelinci. Prosiding SNaPP: Sains, Teknologi, 1(1), 31-48.

[13] Hernani, H., Bunasor, T. K., \& Fitriati, F. (2010). Formula Sabun Transparan Antijamur dengan Bahan Aktif Ekstrak Lengkuas (Alpinia galanga L.Swartz.). Buletin Penelitian Tanaman Rempah Dan Obat, 21(2), 192-205.

[14] Agustini, W. \& Winarni, A. H. (2017). Karakteristik dan Aktivitas Antioksidan pada Sabun Padat Transparan yang Diperkaya Dengan Ekstrak Kasar Karotenoid Chlorella pyrenoidosa. Jurnal Pascapanen dan Bioteknologi Kelautan dan Perikanan, 12(1), 1- 12.

[15] Harnanto, A. dan Ruminten. (2009). Kimia 3 : Untuk SMA/MA Kelas XII. Jakarta: Pusat Perbukuan Departemen Pendidikan Nasional.

[16] Anwar, I. (2010). Pengembangan Bahan Ajar. Bahan Kuliah Online. Bandung: Direktori UPI.

[17] Amin, A. K. (2016). Analisis Bahan Ajar Modul Statistika Pada Program Studi Pendidikan Matematika IKIP PGRI Bojonegoro. Jurnal Pendidikan Edutama, $3(2), 1-8$

[18] Anggraini, A. dan Sukardi. (2017). Pengembangan Modul Prakarya dan Kewirausahaan Materi Pengolahan Berbasis Product Oriented Bagi Peserta Didik SMK. Jurnal Pendidikan Vokasi, 5(3), 287-296.

[19] Eveline, S \& Hartini N. (2014). Teori Belajar dan Pembelajaran. Bogor: Ghalia Indonesia.

[20] Borg, W. R., \& Gall, M.D. (2007). Educational research: an introduction (8th ed.). New York: Longman. 